第 6 回国際污水廃棄物処理技術都市清掃専門展示会 (IFAT' 81$)$
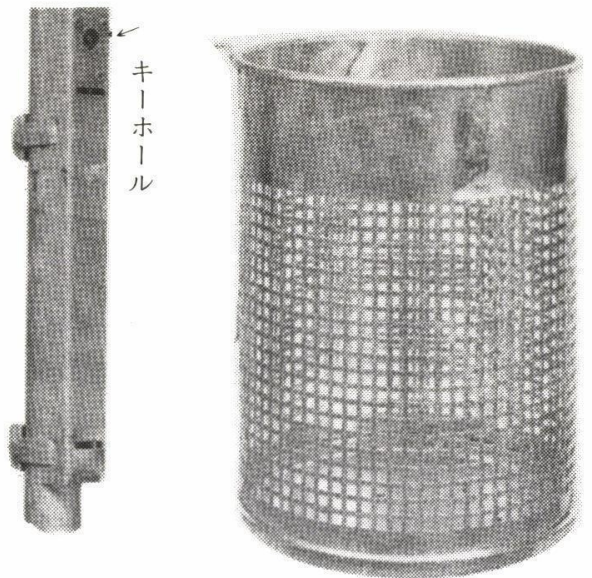

しているあのと思わ机る. どちらの容器も $2 \sim 3 \mathrm{~m}^{3}$ の 大きなもので, クレーン付トラックで荷台の上まで吊 上げ，底を開いて中身を落下させる方法がとられる。 公園なよ゙屋外の公共場所に据付ける紙首入れも数社 から展示されている。デザインは各社異なるが，共通 してキーでロックを外すと籠が支柱から取離せる仕組 みになっていて, 収集人が中身をあけ替え易く考えら れている.

非常に多くの展示物の中から筆者の個人的興味で選 んだものを紹介し，また技術評価む十分なされていな いあのに終って了ったが, 何かの㧍役に立てば幸である.

図-24 Langer 社の紙屑籠 左側の支柱に籠のフックを固定する

\title{
測定方法とコントロール技術
}

\section{Measurement and Control Technology}

伊東 祐 輝 ${ }^{*}$. 加藤 忠 ${ }^{*}$

松永岩 夫*

\section{1 概 要}

IFAT'81に扔いて, 測定方法上コントロール技術, いわゆる計装技術に関する出品会社数は全体の約 $20 \%$, 140社程度であった。

出品内容により分類すると, 測定機器が 120 社程度, コントロール・ステーションが50社程度, 調整装置と コントロール設備が70社程度, 研究室備品が50社程度, それにデータ処理が10余社である.

展示方法は日本の下水道展などと同様, 各社夫々の 趣向により，実機によるデモンストレーションやハハネ ル図示による説明などでPRをはかっていた。
展示会場は日本の下水道展よりはるかに大規模で, 展示場屯, 米国の WPCF 展示会場 (1980 年ラスベガ ス）と同様, 広くゆったりとしていた。 また展示会場 内での休憩場の設置や喫茶, 軽食店の配置などに, 見 学者に対する配慮がうかがえた。

\section{2 計装機器}

工業計器関係では, 水位計や流量計などの発信器や 指示計, 記録計や調節計などの受信計器が展示されて いたが特に目新しいものはなかった。

発信器関係では, 超音波式水位計, 投込式水位計, 開渠式流量計などの実機展示が数多く目についた。

* 富士電機製造 (株) 水処理事業部 技術部 Yuki ITOH, Tadashi KATO, Iwao MATSUNAGA 


\section{特 集 II 第 6 回国際污水廃棄物処理技術都市清掃専門展示会 (IFAT' 81 )}

受信器関係では, 期待したワンループ調節計は見 あたらず, 相変らず従来の可動コイル式の大形計器な よ゙が展示され期待はずれであった。

水質計関係では, pH計，DO計，MLSS計などが展 示されていたが，乙れらのセンサも現在，日本で販売 されていたり，国産化されているものが殆どで特に目 新しいものはない。乙こでは EUR - CONTROL 社の MEX 2 型フォトメータ（SS計）の概要を紹介する.

MEXは, 例えば污泥中の固形物がその光学特性の函 数として測定される場合, すなわち浮遊状態の物質が, 吸収され減衰するという現象を支配するピーアの法則 にしたがう場合と，あるいはチンダル効果に示される ように，浮遊物質が光のエネルギーを散乱させる場合 の両方に使用することができる.

標準型式の検出装置は, フィルターを使用しない通 常の白熱電球とシリコン製のソリッドステート光電管 エレメントを使用している. 検出端の污染, あるいは ランプまたは光電管の特性の变化は, 最高 $90 \%$ 光度 がなくなるまで自動的に補正される.

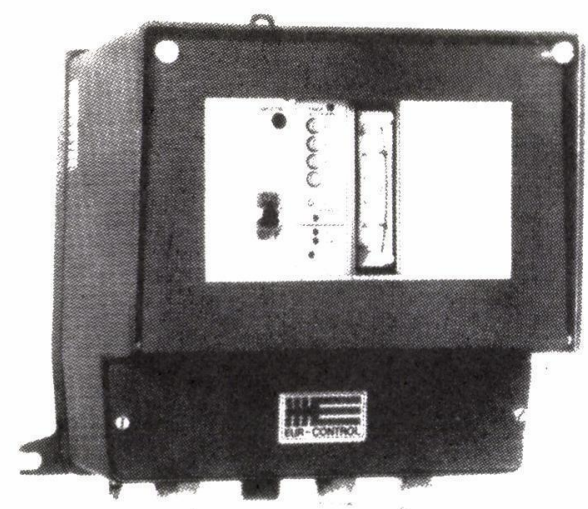

写真-1 SS 計変換器

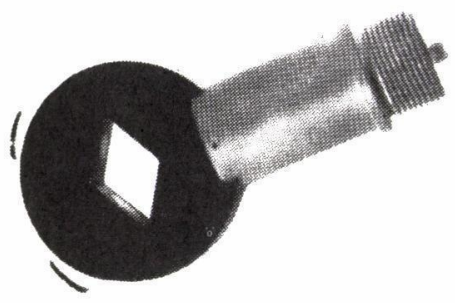

写真-2 SS 計検出器
写真-1にSS計変換器を, 写真-2 亿SS計検出器を示す.

\section{3 管理室機器}

中央管理室の監視操作形態は, CRTディスプレイ中 心で, コンパクト化され，オフィスイメージのものが 多く展示されていた.

グラフィック盤はモザィク式で, 24 山のものが展示 されており，色彩豊かにプロセス系統を模擬図で表示 している. 操作デスクはCRTディスプレイ中心でコン パクト化されてきて簡素化の傾向になっているが，管 理室全体はシステム化されており, モザィク式グラ フィック盤, CRTディスプレイ, 操作デスク, タイプ ライタなどが機能的に配置されている。

欧州ではCRT上同時にグラフィックパネルも重視し ているようである。写真-3に展示例を示す。

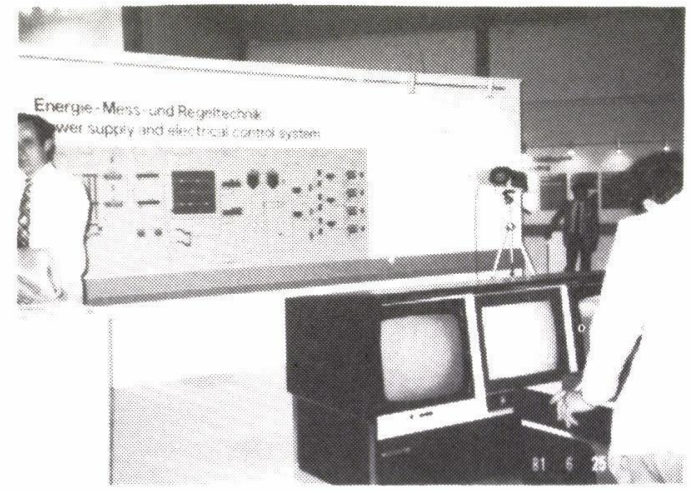

写真-3 計装システム展示例

\section{4 デジタル計装システム}

マイクロコンピュータ応用機器により機能分散され たデジタル計装システムについても数社が展示してい た。これらはシステムの操作, 取扱および保守に関し て, 専門的知識老必要とせず, プログラミングはCRT ディスプレイ装置を利用し対話形式にて行うなよ゙，日 本に打りる動向と同じである.

代表例としてHARTMANN\& BRAUN社の, マイク ロエレクトロニクス技術を応用したデジタル式プロセ ス計装システムCONTRONIC-Pの概要を紹介する.

CONTRONIC-P の特徵

（1）ループ制御，シーケンス制御㧍よびモニタリンク の機能を統合した自動化のためのシステムであり, 


\section{第 6 回国際污水廃棄物処理技術都市清掃専門展示会 (IFAT'81)}

プロセスの監視，操作抢よび記録作成の機能ととも にCRTディスプレイ表示む行うことができる.

(2) マイクロプロセッサとデータウェイBUSによる機 能分散システムである。また階層化システム構成が 叮能で，空間的に分散した自動化システムの構築も 可能である。

(3) メモリプログラミング方式のシステムであるが, プログラミングの知識がなくとも取扱いが可能であ る. 機能定義とパラメータ設定は対話方式を採用し 与えられている機能から選択して行う.

(4) 自己診断および故障診断が可能で, データ伝送, データ処理, 監視および操作機能の冗長化が行える.

(5) 従来の計装, H\& B プロセス制御システム $\mathrm{PRO}$ TRONICの計装機器よの混在が川能である.

図-1にCONTRONIC-P システムの基本構成図を示す。 プロセスステーションでは, ループ制御, シーケン ス制御执よびモニタリングの機能を持たせることがで きる.プロセス入出力用としてモジュール形式のプロ セスインターフェイスユニットが装され, フィール ドの発信器, 変換器抢よび操作機上接続している.

プロセスステーションは, その機能の面で単独シス テムであり，独汹の目動化ユニットとして，または， より大規模な制御システムの最小計装モジュールとし ても使用できる.

プロセスステーショシは12ループの制御, あるいは 128 点のシーケンス制御也力, あるいは 256 点のアナ ログ信号入力, あるいは 512 点の接点信号入力, ある いはこれらの組命わせが川能である。

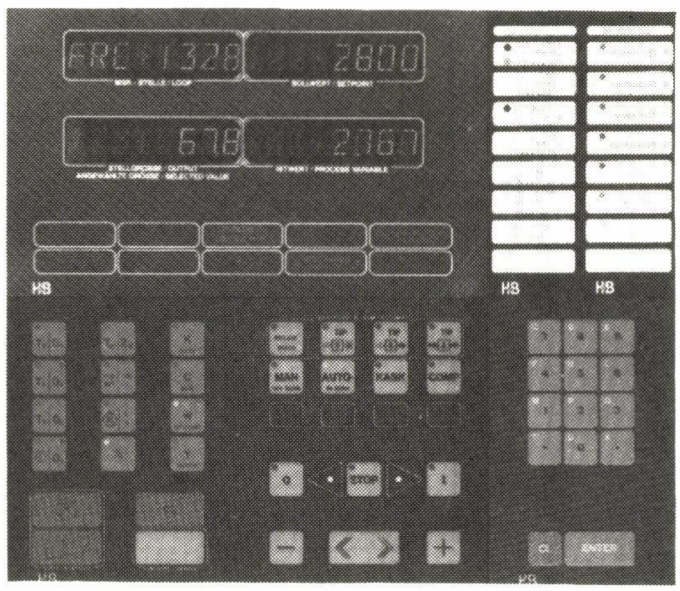

写真-4 ステーション操作ユニット
プロセスステーションをスタンドアロンシステムと して使用する場合には, 監視操作用にV.24 インター フェイスを介してデジタル表示执よびキーボードにて 構成されたステーション操作ユニットを設置する.

写真-4にステーション操作ユニットを示す.

また, より大規模な制御システムの場合には，同軸 ケーブルによるシステムBUSにて, プロセスステーショ ン相互間掠よび, 例えばグループマスターステーショ ンあるいは中央マスターステーションのような, 上位 の中央ステーションと接続することができる.

システムBUSには 127 個までのステーションを接続 できる. また, この BUSは $4.5 \mathrm{~km}$ まで延長でき, デー 夕伝送速度は $1 \mathrm{Mbit} / \mathrm{sec}$ である.

中央マスターステーションは 1 個あるいは数個のC RTディスプレイ装置を接続し, ステーション操作ユ ニットと同様な,ループ制御, シーケンス制御および モニタリング機能の集中監視操作が可能である.

写真-5に中央マスターステーションを示す.

中央マスターステーションにはドキュメンテーショ ン用として, 運転記録報告プリンタ, CRTコピー, 夕 イプライタなよ゙を設置することができる.

可搬式コンフィギュレーションユニットにより個々 の分散プロセスステーションの機能定義やパラメータ 設定が可能である.

コーディネータステーションは階層システム用の複 数のプロセスステーションの相互連絡の機能を持つ.

大型プラントに扔ける診断ステーションはシステム の自己診断に関する全てのメッセージを分析評価し，

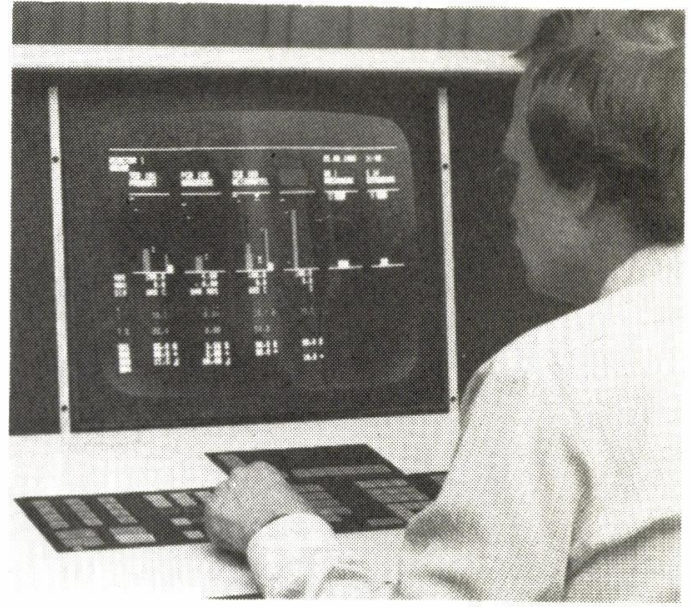

写真-5 中央マスターステーション 
特 集 II 第 6 回国際污水廃棄物処理技術都市清掃専門展示会 (IFAT'81)

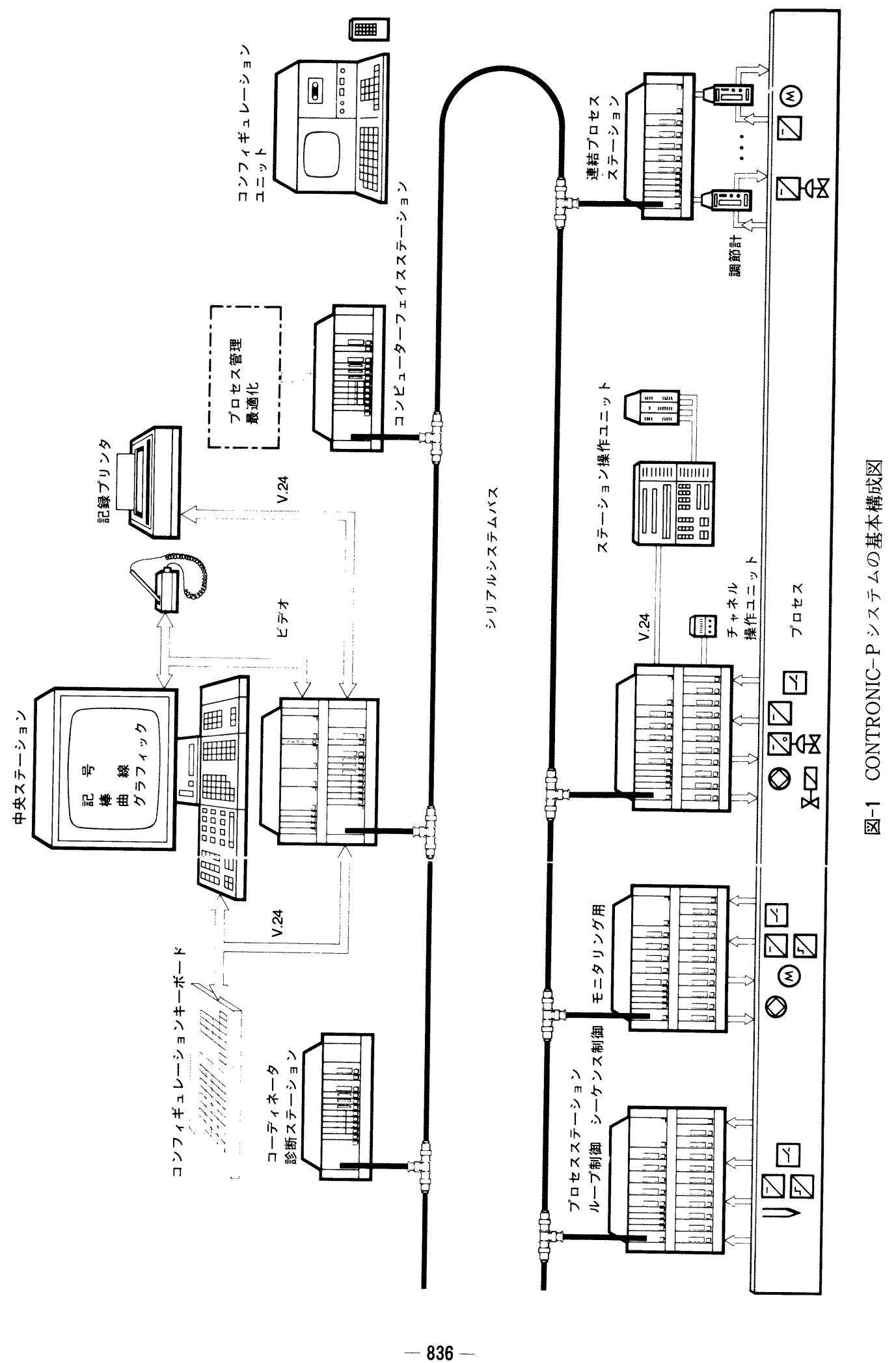




\section{第 6 回国際污水廃棄物処理技術都市清掃専門展示会 (IFAT' 81$)$}

処理する.

連結プロセスステーションを介して H＆B プロセス 制御システムPROTRONIC計装機器をシステム BUS に 接続できる.

コンピュータインターフェイスステーションは, プ ロセスの総合管理や最適化のような上位機能処理のた めに, プロセスコンピュータと情報交換を行う場合に 使用する.

\section{5 情報処理システム}

マイクロコンピュータの技術進歩により，プロセス 制御用計算機システムは, 中規模処理場の集中管理用 や大規模処理場のマイコンの上位機種として位置付け られてきている. 一方, CRT ディスプレイを中心とす る監視操作のニーズに対応し,より高度化された CRT ディスプレイ機能をもつ計算機システムが展示されて いた.ここでは, SIEMENS 社の EAF形 CRT ディス プレイ装置について紹介する.

EAFはローリングマップと呼ばれる CRT 画面管理 方式である。乙れは, 計算機があたかも首を振りなが らプロセスを監視しているかの如く, 操作デスク上の ジョイスティック操作により, ディスプレイ画面が, 上下左右に自在に移動するものである.

CRT 画面操作方法はライトペンとバーチャルキー ボードを主体としている.バーチャルキーボードは CRT 画面の下部に表示され, ライトペンでキー選択操作を 行うものである.

アプリケーション機能, すなわちプロセス入出力の 定義やプロセス系統画面をライトペンによる対話方式 にて簡単に作成することができる.

機器操作機能として, ポンプの起動, 停止やバルブ の開閉操作指令を, プロセス系統画面を利用して行う ことが可能である. 操作手順は, まずバーチャルキー ボードの「運転」をライトペンで選択し, 系統画面の 該当する機器をライトペンで選択するとシンボルがブ リンクし，「実行」押釦ランプが点灯する. 次に, この 「実行」押釦を押すとランプが消灯し, 運転信号が出 力される. 最後に, 機器の「運転」信号が入力された 時点で, 機器のシンボルが運転状態になり, タイプラ イタに機器運転のメッセージが記録される.

写真-6に CRT 画面走す.

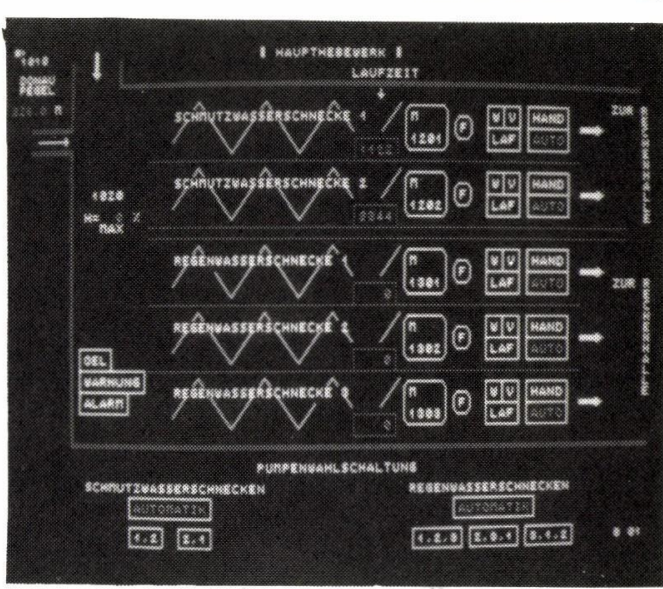

写真-6 CRT 画面例

\section{6 河川水質モニタ}

河川水質分析計の代表例として AEG-TELEFUNK $\mathrm{EN}$ 社のラインおよびモーゼル両河川の管理に使用さ れている自動水質分析装置について述べる.

同社はライン河畔のマインツ, ヴィスバーデン括よ びモーゼル河畔のファンケルに水質コントロールステー ションの設備を納入している.

ライン川水質コントロールステーションは 4 個の橋 脚に水中ポンプを設置し, 水を最大長 $600 \mathrm{~m}$ の断熱配 管を通してライン河畔のコントロールステーションに 導びいている. ステーションには合計14台の自動分析 装置を設置し，下記により構成されている.

4 台一 $\mathrm{O}_{2}, \mathrm{pH}$, 導電率, 温度用測定装置

4 台一濁度計

2 台一 $\mathrm{PO}_{4}, \mathrm{COD}, \mathrm{NH}_{4}, \mathrm{NO}_{2}+\mathrm{NO}_{3}$ 用分析計

1 台一 $\gamma$ 線および $\beta$ 線用放射能測定装置

1 台一TOC自動測定装置

1 台一魚による警報装置

1 台一バクテリア毒物計

$\mathrm{O}_{2}, \mathrm{pH}$, 導電率, 温度扔よび濁度测定装置は直接 4 本の測定水路で稼動し, その他の自動分析装置は30 分の周期で順次 4 本の個別水路に接続している.

モーゼル川水質コントロールステーションはファン ケルにあり，モーゼル河畔の 4 ケ所で測定された水中 に溶存している酸素濃度データを遠方伝送装置を通じ 30 秒間隔で受信している. 第 5 測定点がファンケルに ある.乙こで $\mathrm{O}_{2}, \mathrm{pH}$, 水温, 導電率および日照を自 動的に（河川水の酸素管理における効率係数として） 


\section{特 集 II 第 6 回国際污水廃棄物処理技術都市清掃専門展示会（IFAT'81）}

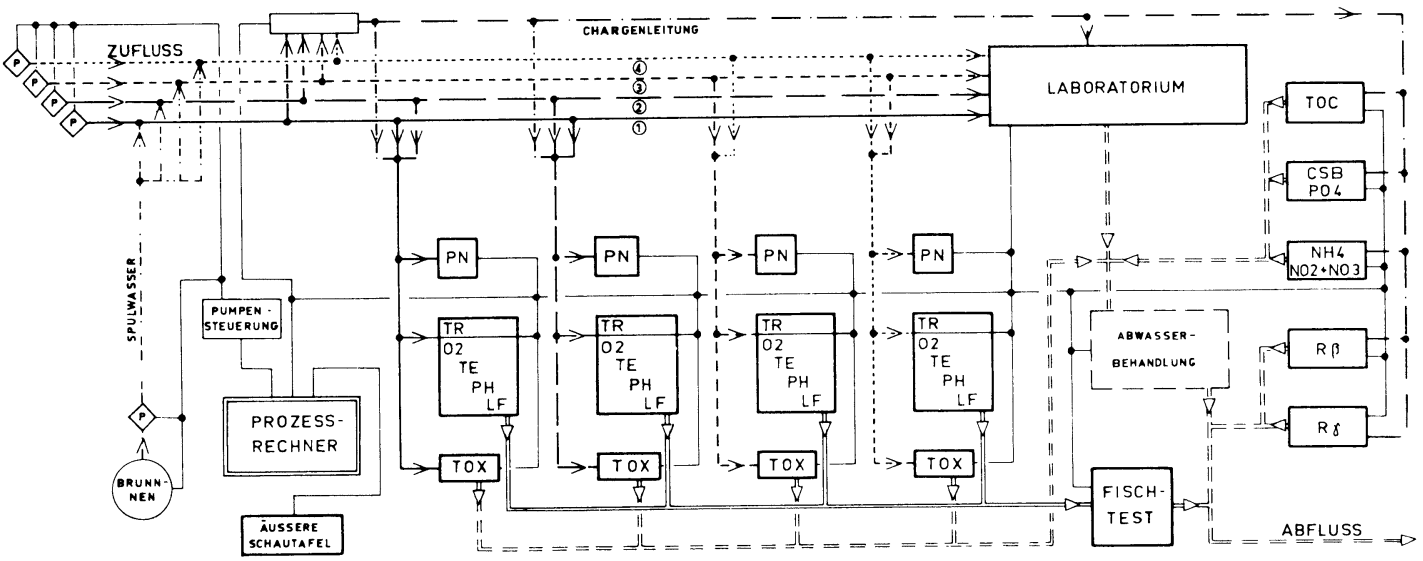

図-2 ライン川水質コントロールステーション概要図

測定している.

マインツではプロセスコンピュータ AEG 80-20に よるデータロガーGEADAT 80にて，水質測定データ の処理と, 水質コントロールセンタの制御を行ってい る. 制御装置は測定水の供給や測定水路の定期的洗浄 および，自動分析装置の測定，検定および分析評価サ イクルを対象としてコントロールしている.

ファンケルではマイクロプロセッサALU80による データロガーGEADAT80亿て，5 ケ所の各モーゼル ステーションの測定值の時間平均值算出などのデータ
処理を行っている.

収集データは, 異常負荷事例に対する緊急措置の場 合の決定手段として用いている．例えば，ライン川が 異常に污染した場合, 水力発電所は採水前に警報を受 けることが出来る。

測定值の中間扢よび長期分析評価，およびそり記録 保管もデータ処理装置によって簡易化され，経済的な 形態となっている.

図-2にライン川水質コントロールステーション概要四 を示す。

\section{污水溝システム}

川下好 則

\section{まえがき}

IAWPR (国際水質污濁研究会議), IFAT (国際下水 処理, 処分貿易見本市); ISW A (国際廃棄物都市清掃 会議)，に参加する前に6月 15 日〜19日まで東京晴海
に於いて'81下水道展が開かれたのを短時間であった が，見学する機会をえたので上記 IFAT と比較しなが ら, ヨーロッパの下水道展特に管路, 排水設備につい て述べることにする.

*侏都市建設コンサルタント社長 Yoshinori KAWASHI TA 